\title{
Computer Simulation Study: An Impact of Roadside Illegal Parking at Signalised Intersection
}

\author{
Noorazila Asman ${ }^{1}$, Munzilah Md Rohani ${ }^{2}$, Nursitihazlin Ahmad Termida ${ }^{3}$ \\ Noor Yasmin Zainun ${ }^{4}$, Nur Fatin Lyana Rahimi ${ }^{5}$ \\ Department of Infrastructure Engineering and Geomatic 1, 2,3,5 \\ Department of Building and Construction Engineering ${ }^{4}$ \\ Faculty of Civil and Environmental Engineering \\ Universiti Tun Hussein Onn Malaysia \\ Parit Raja, Batu Pahat \\ Johor, Malaysia
}

\begin{abstract}
Traffic congestion could be a serious road traffic problem particularly at intersections because of its potential impact on the risk of accidents, vehicle delays and exhaust emissions. In addition, illegal parking by road users at intersections can give additional deterioration to the intersections that may create additional traffic flow interruptions. This paper presented assessment of the illegal parking impact on signalized intersection at Parit Raja, Malaysia using simulation approach using PTV VISSIM simulation software. The results showed that if illegal parkings at Parit Raja intersection were banned, traffic delay and travel time of vehicles will be improved and thus, improving the intersection Level of Service.
\end{abstract}

Keywords-Traffic simulation; traffic flow; signalized intersection; level of service; illegal parking

\section{INTRODUCTION}

Congestion was associated with the necessity and ability to own personal vehicle. This was interrelated to an increment in population and income level that people become affluent to owning vehicles [1]. The increment in traffic volumes on the road contribute to the movement conflict, long queue and stop delays at intersections. In order to reduce congestion at an intersection, traffic signal is introduced. Signalized intersection allows the traffic to cross the road safely as the traffic will be directed to passage in sequence and allow them to cross without obstacles. Signalized intersection, apparently, can reduce right angle accidents, increase road capacity, bring confidence to drivers to cross the roads and provide a good level of service. Although the main function of traffic lights is to reduce the traffic conflict at intersections, installing traffic control devices at intersection areas do not always give an advantage to road users. For example, installing unnecessary traffic control devices can result in disturbing the traffic flows instead of improving it. The installation of traffic lights at intersections can also create other harms to road users such as rear-end crashes and traffic delays [2]. Rear-end accidents at signalized intersections usually occurred because of the leading vehicles' sudden stop due to signal change or traffic situation and drivers' eyes tend to focus on the traffic light rather than the vehicle right in front of them [3]. This kind of situation will slow down the traffic flows at intersections.
In addition, parking on the road sides can have an impact on traffic flows mainly if it is closer to the intersection as it reduces road capacity. Furthermore, side parking can delay or block any movement of vehicles, particularly for left turnings [4]. In India, it was reported that parking was one of the serious problems in urban areas that the country was facing due to the increment of vehicle ownership and the development of mall within the city center [5]. Malaysia is also experiencing similar problems. This is including the illegal parking in unauthorized areas, particularly near the road intersection. Illegal parking on roadsides reduces the effective width of the lane and hence reducing the speed and capacity of the prevailing roadways. As a result, the traffic will be interrupted which cause delays, accidents, congestion, etc.

In previous years, the assessment of the signalized intersections performance had used various approaches that focused on the application of software. Simulation by using software was one among the most popular methods including SUMO, TRANSIMS and PTV VISSIM [6]. These software programs were able to produce simulations of traffic flows and various scenes of traffic operation at signalized intersections without disturbing the traffic at the actual locations to detect any problem occurring at the signalized intersections. The significant of this study was evaluation on the impact of illegal parking by measuring level of service (LOS) on the road for two scenarios, which are road with illegal parking and road without illegal parking.

\section{CASE StUdy: PARIT RAJA SignAlized INTERSECTION}

This study had been conducted at a signalized intersection located at Parit Raja, Batu Pahat, Malaysia (Fig. 1). The town of Parit Raja was one of the busiest areas in Batu Pahat as it is the main destination for businesses and occupations. There were shop lots, banks, offices, industrial areas and educational institutional buildings within the small town. Parit Raja signalized intersection was an important junction which connects two main cities, Kluang and Batu Pahat. 


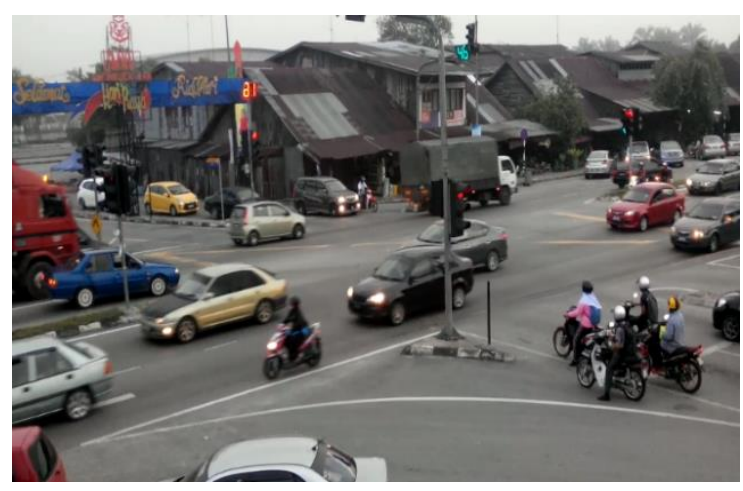

Fig. 1. Study Location.

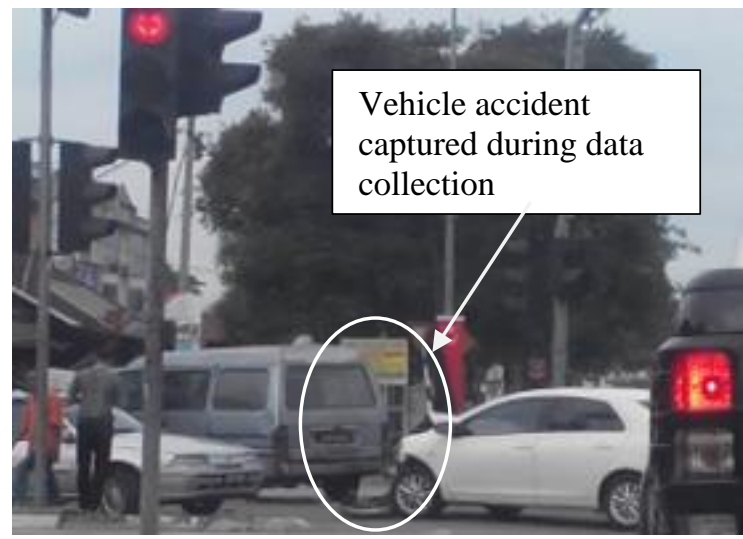

Fig. 2. Vehicle Accident at Parit Raja Signalized Intersection.

Parit Raja intersection was a four-legged junction and controlled by traffic signals. From the traffic study conducted, traffic flow at Parit Raja intersection had the highest traffic volume during morning peak hours at 7.00 to $9.00 \mathrm{am}$. During this period, traffic flow was mostly dominated by road users who live nearby. Accidents still occur at the Parit Raja signalized intersection even when the intersection was controlled by traffic signals (Fig. 2). Social activities such as businesses on the road curbs encourage people to illegally park their vehicles on the side of the roads, affecting the traffic flow. This study simulates traffic flow at Parit Raja signalized intersection using PTV VISSIM software and investigate the impact of illegal parking at the intersection. This study only limits to $2 \mathrm{~km}$ radius from the intersection area and pedestrian factor were excluded.

\section{Methodology AND ReSEARCh DAtA}

PTV VISSIM is the software which has the function of simulates various scenes of traffic operation [6]. The software is able to simulate the traffic situation either by $2 \mathrm{D}$ or $3 \mathrm{D}$. In order to replicate the traffic flow at the study areas, real data were needed. Table I shows specific parameters used as an entry data for this study. To simulate the traffic flow at study site, three groups of data were mandatory to be keyed in the software database were;(1) road geometry; (2) traffic; and (3) signal control data.

In this study, traffic volume study was performed by conducting video recording to record vehicle movements of all traffic directions at the intersection. The data were recorded in two peak hours sessions: two hours in the morning (7:00 am to 9:00 am) and two hours in the evening (5:00 pm to 7:00 pm) for five days during the weekday. Data collected were including number of vehicle movement based on vehicle types and direction of all vehicle movements. As principally required by the traffic flow analysis study, traffic volume count had been conducted according to an hourly basis during data collection period (throughout the 2 session of data collection). However, for data analysis, only 1 hour of any day of uppermost traffic volume data had been selected to be simulated. The selection of data for analysis was done based on critical traffic situation factor. The consideration was taken because during this situation, maximum traffic problem was expected to be occurred. Fig. 3 shows the summary of 1 hour highest volume traffic observed from the site. From the data gathered, it was found that the highest traffic volume was on Wednesday while Sunday has the lowest volume (shown in Fig. 3). Fig. 4 presents specifically peak hour traffic volume summary data used in this study while Table II summarized specific traffic composition used in the simulation.

TABLE. I. DATA PARAMETERS

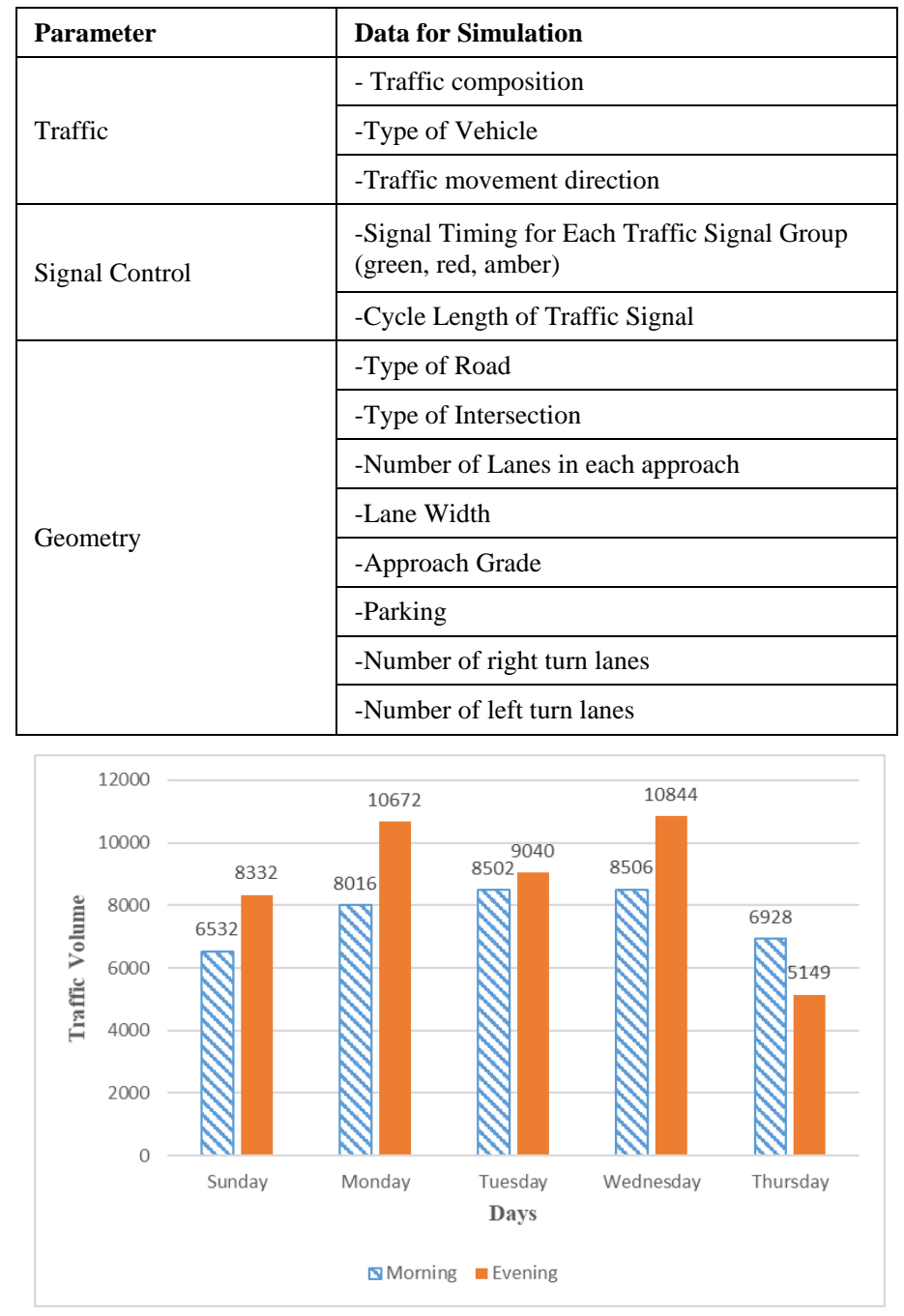

Fig. 3. Showing Graph Traffic Volume at Study Location. 
TABLE. II. TRAFFIC COMPOSITION GATHERED FROM STUDY LOCATION

\begin{tabular}{|c|c|c|c|c|c|c|c|c|c|c|c|c|c|c|}
\hline \multirow{2}{*}{$\begin{array}{l}\begin{array}{l}\text { Vehicle } \\
\text { movement }\end{array} \\
\text { Movement } \\
\text { Direction / } \\
\text { Type of } \\
\text { Vehicle }\end{array}$} & \multicolumn{4}{|c|}{ From Batu Pahat } & \multicolumn{4}{|c|}{ From Kluang } & \multicolumn{3}{|c|}{ From Parit Raja Laut } & \multicolumn{3}{|c|}{ From Parit Raja Darat } \\
\hline & $\begin{array}{l}\text { Turn } \\
\text { Right }\end{array}$ & $\begin{array}{l}\text { Throu } \\
\text { gh }\end{array}$ & $\begin{array}{l}\text { Turn } \\
\text { Left }\end{array}$ & $\begin{array}{l}\text { U- } \\
\text { Turn }\end{array}$ & $\begin{array}{l}\text { Turn } \\
\text { Right }\end{array}$ & $\begin{array}{l}\text { Throu } \\
\text { gh }\end{array}$ & $\begin{array}{l}\text { Turn } \\
\text { Left }\end{array}$ & $\begin{array}{l}\text { U- } \\
\text { Turn }\end{array}$ & $\begin{array}{l}\text { Turn } \\
\text { Right }\end{array}$ & $\begin{array}{l}\text { Throu } \\
\text { gh }\end{array}$ & $\begin{array}{l}\text { Turn } \\
\text { Left }\end{array}$ & $\begin{array}{l}\text { Turn } \\
\text { Right }\end{array}$ & $\begin{array}{l}\text { Throu } \\
\text { gh }\end{array}$ & $\begin{array}{l}\text { Turn } \\
\text { Left }\end{array}$ \\
\hline Car & 244 & 1200 & 180 & 64 & 112 & 904 & 96 & 80 & 156 & 112 & 16 & 212 & 60 & 216 \\
\hline Motorcycle & 164 & 332 & 80 & 32 & 52 & 192 & 108 & 44 & 60 & 172 & 28 & 60 & 152 & 92 \\
\hline Bus & 0 & 8 & 0 & 0 & 0 & 8 & 0 & 0 & 0 & 0 & 0 & 0 & 0 & 0 \\
\hline $\mathrm{HGV}$ & 8 & 68 & 4 & 0 & 4 & 136 & 8 & 0 & 12 & 0 & 0 & 4 & 4 & 8 \\
\hline Total & 416 & 1608 & 264 & 96 & 168 & 1240 & 212 & 124 & 228 & 284 & 44 & 276 & 216 & 316 \\
\hline $\begin{array}{l}\text { Volume } \\
\text { Percent }\end{array}$ & 17.5 & 67.5 & 11.1 & 4.0 & 9.6 & 71.1 & 12.2 & 7.1 & 41.0 & 51.0 & 7.9 & 34.2 & 26.7 & 39.1 \\
\hline $\begin{array}{l}\text { Total } \\
\text { Volume }\end{array}$ & \multicolumn{4}{|l|}{2384} & \multicolumn{4}{|l|}{1744} & \multicolumn{3}{|l|}{556} & \multicolumn{3}{|l|}{808} \\
\hline$\% \mathrm{Car}$ & 58.7 & 74.6 & 68.2 & 66.7 & 66.7 & 73.2 & 45.3 & 64.5 & 68.4 & 39.4 & 36.4 & 76.8 & 27.8 & 68.4 \\
\hline $\begin{array}{l}\% \\
\text { Motorcycle }\end{array}$ & 39.4 & 20.7 & 30.3 & 33.3 & 31 & 15.5 & 50.9 & 35.5 & 26.3 & 60.6 & 63.6 & 21.7 & 70.4 & 29.1 \\
\hline$\%$ Bus & 0 & 0.5 & 0 & 0 & 0 & 0.65 & 0 & 0 & 0 & 0 & 0 & 0 & 0 & 0 \\
\hline$\% \mathrm{HGV}$ & 1.9 & 4.2 & 1.5 & 0 & 2.4 & 10.6 & 3.8 & 0 & 5.3 & 0 & 0 & 1.5 & 1.9 & 2.5 \\
\hline
\end{tabular}

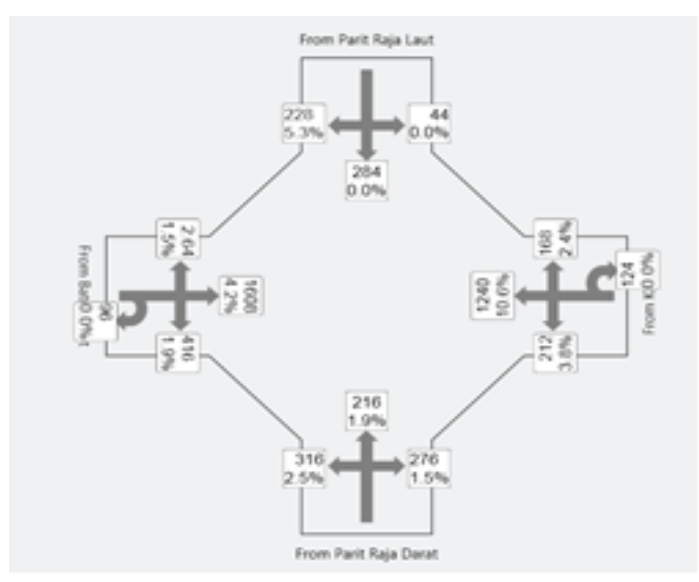

Fig. 4. Summary of Peak Hour Volume at Study Location.

Geometrical data was an important parameter in preparing the simulation in this study. In real condition, geometric data such as number of lanes, lane width, road gradient, parking etc. could influence the capacity and rate of flow. Therefore, to ensure that the simulation represents the actual condition on-site, geometric measurement was performed. Information collected was used as a basis to construct network in the VISSIM. Summary of geometrical data for Parit Raja intersection was shown in Fig. 6, while Fig. 7 shows the layout of the intersection.

Traffic movement at the studied intersection was controlled by pre-timed traffic signal. The signal had been designed with four phases as exhibited in Fig. 5. Specifically, traffic signal cycle time captured on-site was shown in Table III
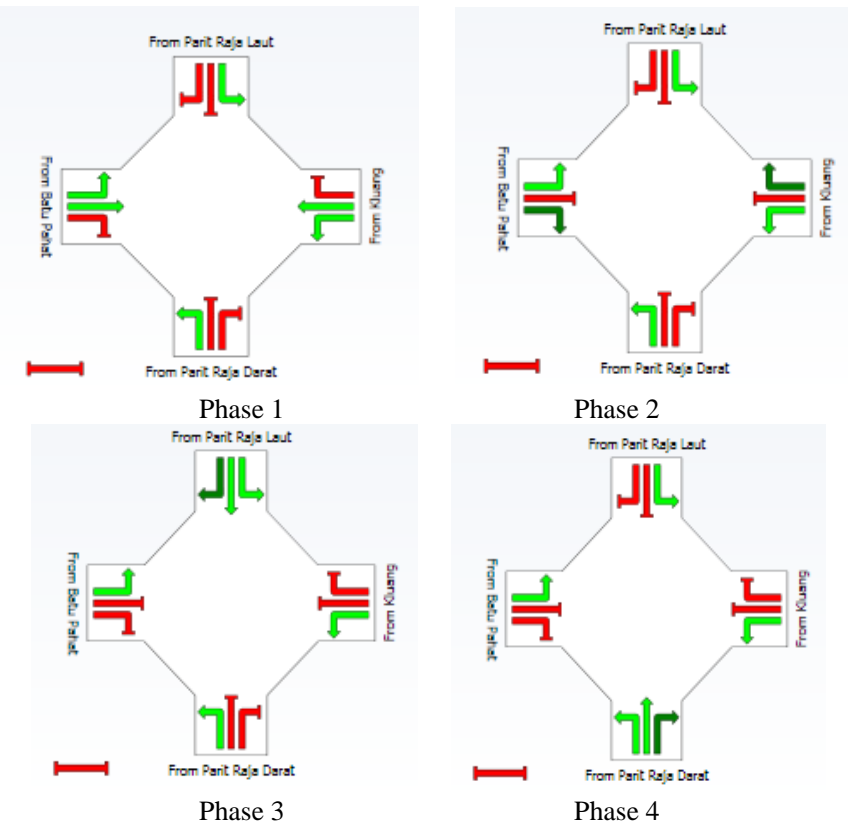

Phase 2

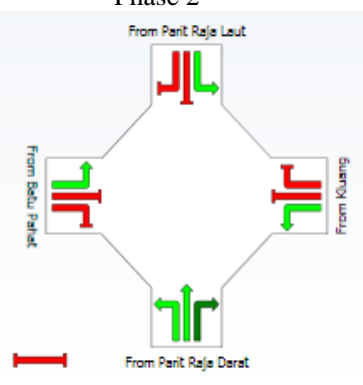

Phase 4

Fig. 5. Traffic Signal Phase for Studied Intersection.

TABLE. III. Cycle Time on Each Movement Phase

\begin{tabular}{|l|l|l|l|l|}
\hline Phase & All Red & Amber & Red & Green \\
\hline Phase 1 & 2 & 4 & 89 & 60 \\
\hline Phase 2 & 2 & 4 & 124 & 25 \\
\hline Phase 3 & 2 & 4 & 124 & 25 \\
\hline Phase 4 & 2 & 4 & 124 & 25 \\
\hline
\end{tabular}




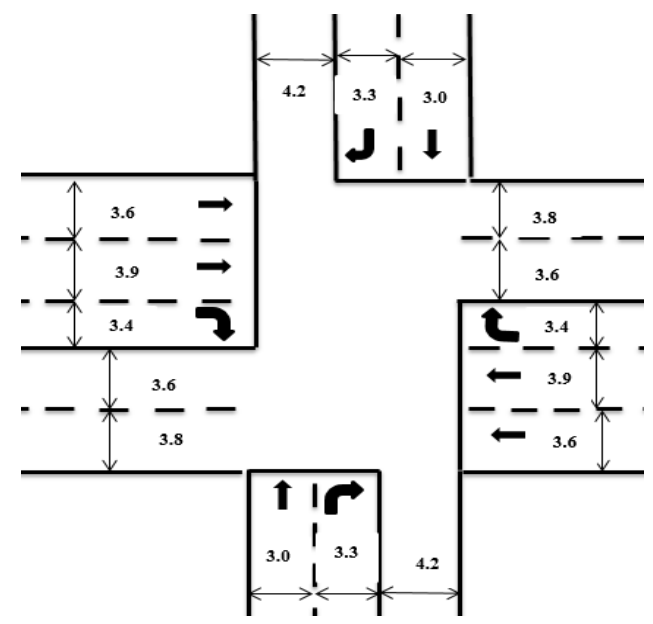

Fig. 6. Lane width of the Studied Intersection.

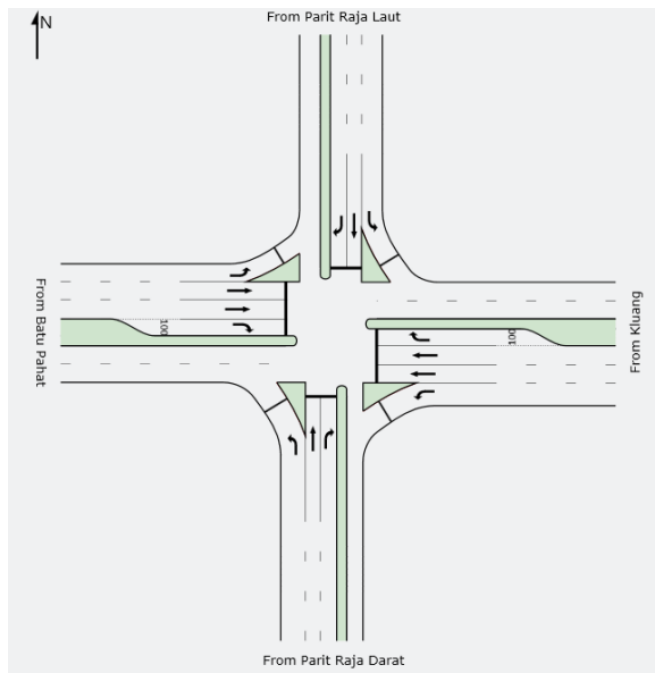

Fig. 7. Intersection Layout at Study Location.

\section{Simulation MOdEL}

In this study, traffic flow simulations were simulated using three different random seeds of 32, 42 and 52. The purpose of different random seed was to check the realization of the stochastic quantities in PTV VISSIM [7] such as vehicle capabilities at the study location. Microscopic modeling in this study can produce results such as flow, density, speed, travel and delay time, long queues, stops, pollution, fuel consumption and shock waves [8]. The results from the simulation such as delays and queues for the intersection were used to evaluate the level of service at Parit Raja signalized intersection.

Network and signalized intersection models need to be set before traffic flow simulation could be run or produced. A brief explanation on how to set a few settings in the software before a simulation could be done and how simulation results will be analyzed were explained as follows:

\section{A. Simulation Parameter Setting}

Simulation parameter defines the smoothness movement of simulation. Time duration for the simulation was suggested at 4,500 seconds by PTV VISSIM, which was one hour for running the simulations, and 15 minutes for adding input in the software. Simulation resolution was measured as number of steps per second that defines the frequency of vehicle movements in one second of the simulation. 1 to 20 time steps/simulation second was the value that can be used in the simulation resolution. While, 10 to 20 time steps/ simulation second were the suitable values to ensure the movement flow of the simulation and vehicle smooth. In this study, 10 time steps/ simulation second were used. Random Seed could be defined with different values for every simulation running. Simulation needed to be run using different values of random seed to produce better simulation quality. This study used 32, 42 and 52 random seeds and the speed of simulation speed was 10 in the simulation. Simulation speed can be defined as number of simulation seconds compared to the real time second.

\section{B. Network Setting}

There are lists in a network setting for simulation such as vehicle behavior, unit of simulation, attribute, display and pedestrian behavior. In this study, only vehicle behavior needed to be set as right-hand traffic. Attribute, display and pedestrian behavior were set as default setting as it was assumed as a standard behavior in this study.

\section{Road Link Setting}

Field location map for background in the software was imported from Google maps. The background image was set with suitable scale for the model. After setting the scale, road link could be drawn according to the background image. Lane width was entered in the software before the link was drawn. To connect from one link to another, a connector were drawn. All links need to be connected with each other in developing road network.

\section{Traffic Based Data}

Before the traffic data were entered into a software database, vehicle volume by time interval could be set from 0$900,900-180$ or $900-m a x$. In this study, time interval $0-\max$ was used to collect data from 0-maximum second in the simulation which means the data was collected from the beginning of the simulation until the simulation ended. The data collected were used to determine vehicle queue lengths and vehicle delays at traffic signals. A traffic model needed vehicle volume data per hour as a primary data. Vehicle composition value was entered in the software. Relative flow for each direction could be set according to the percentage data of vehicle for each direction.

\section{E. Signal Control Setting}

Signal control needed to be set according to the signal group at the study location. Signal control also needed to be defined according to its type whether it was a fixed time or actuated. However, in a student version of the PTV VISSIM software, signal control type could only be set as fixed time. The dialog box for editing time for signal control group will appear after the edit signal control was clicked. Cycle time, green time, amber and red time have been set based on the actual traffic signal phase time observed from the study area. The advantage of this software was that the sequence of red, amber and red of signal control also could be reformed for further analysis. 


\section{RESUlT AND DiSCUSSION}

From VISSIM simulations, various results could be obtained to show intersection performances such as vehicle delays and queues. In this analysis, the random seeds used were 32, 42 and 52. Time interval for the result was 100 for every 600 second.

Fig. 8 shows 2D graphical result of the existing traffic condition (with the presence of illegal parking) while Fig. 9 shows the condition if illegal parking was eliminated.

Vehicles in the simulation for this study had been prepared with different colors to characterize four types of vehicles: (1) red for cars, (2) yellow for motorcycles, (3) green for buses, and (4) blue for heavy good vehicles. The white cars in
Fig. 8 represented as cars that were parked illegally. Parking lot was added in the simulation to represent illegal parking areas.

Tables IV and V show the analysis outcome of delay and travel time of the existing traffic (with the presence of illegal parking). Average delay stop for this simulation was 44.15 second and average travel time for the vehicle was 139.62 second. This showed that, each driver had to wait at least 2 to 3 minutes to cross the intersection.

Table VII shows the queue length results for every random seed on each traffic direction. The highest queue length was from Batu Pahat to Kluang with $74.74 m$ length and the shortest queue length was from Kluang to Parit Raja Laut with $2.6 \mathrm{~m}$ distance.

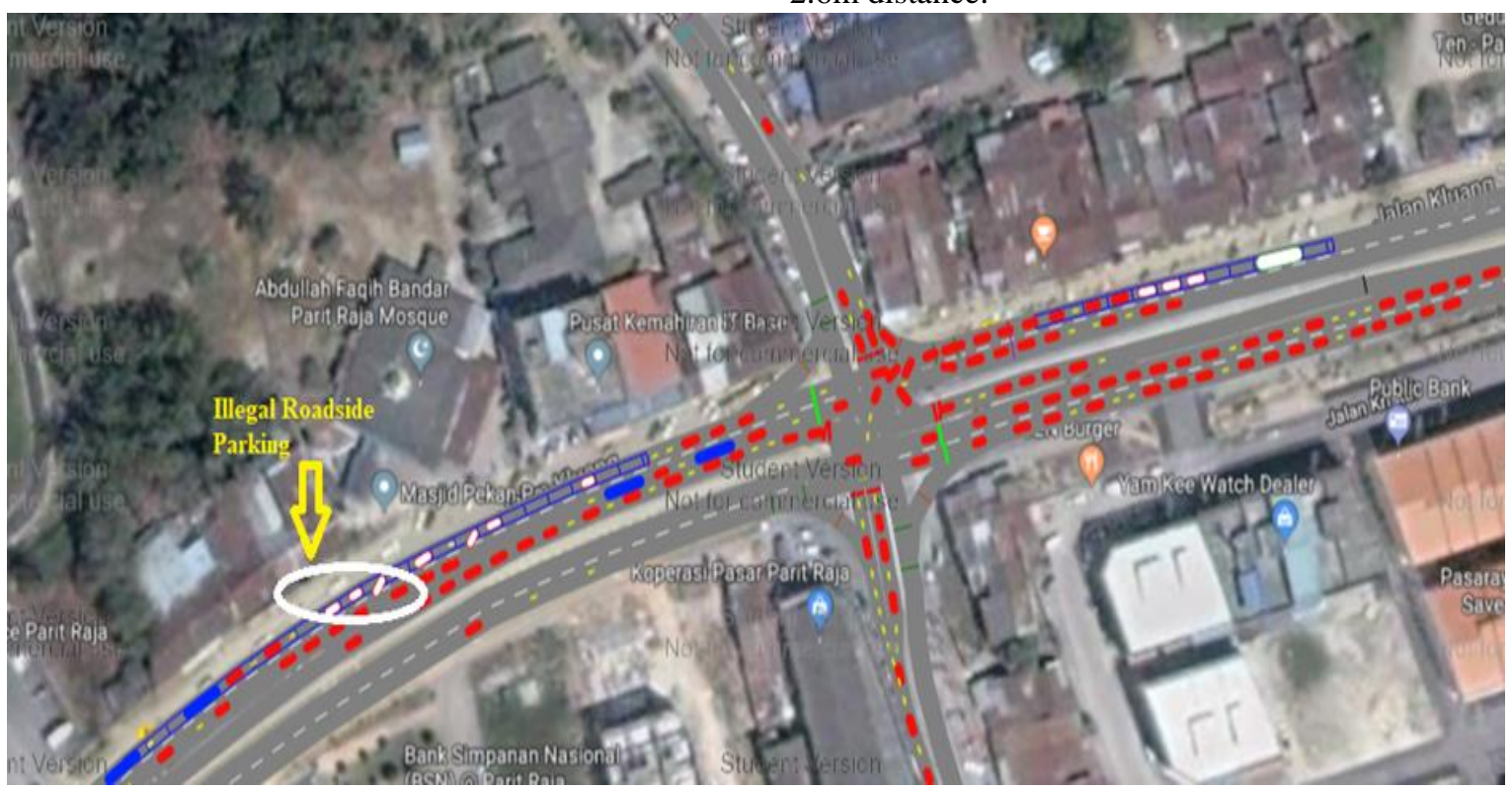

Fig. 8. Simulation of Signalized Intersection Condition at Study Location for Existing Condition (with Illegal Parking).

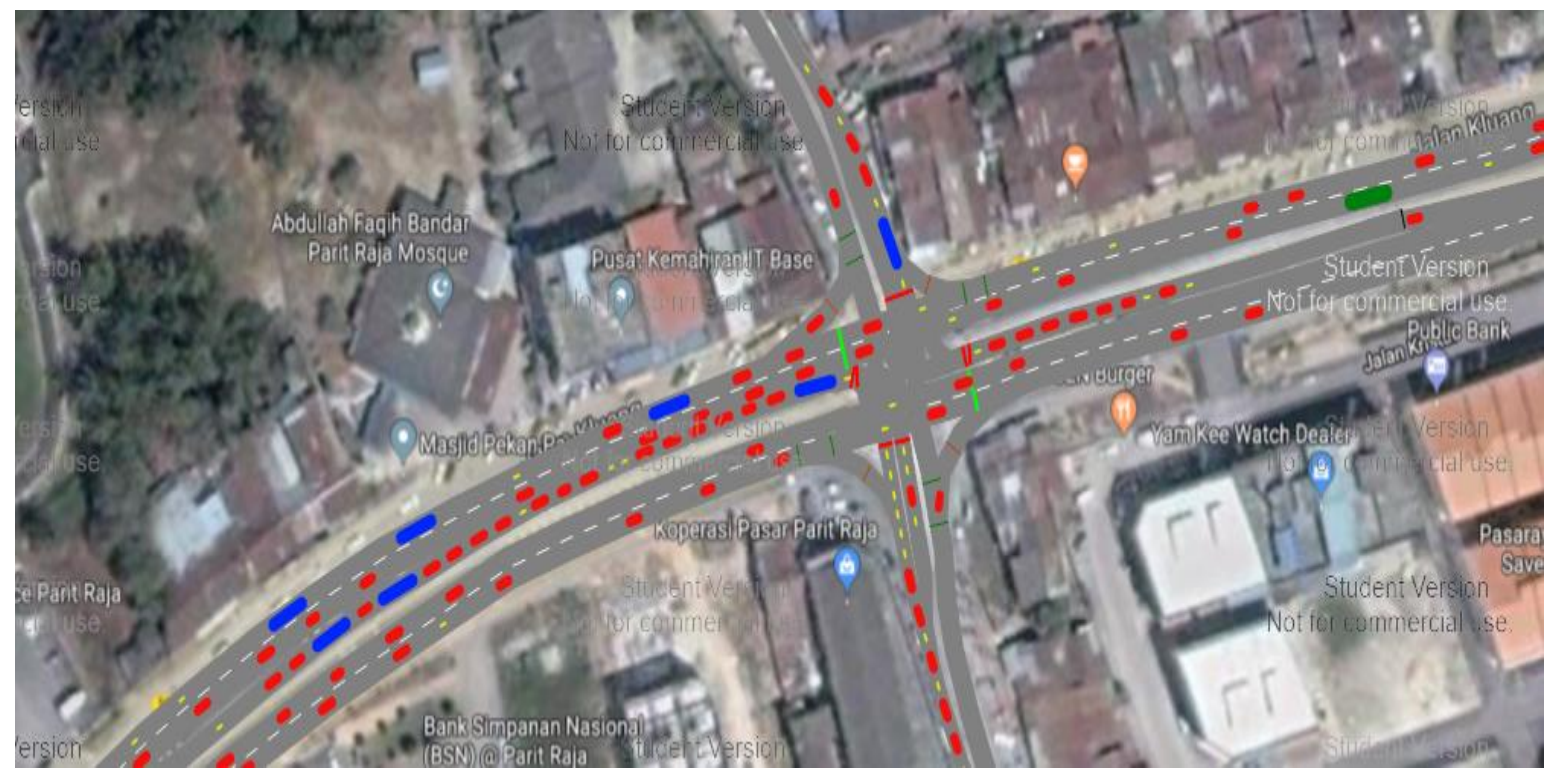

Fig. 9. Simulation of Signalized Intersection Condition at Study Location without Illegal Parking. 
TABLE. IV. STop Delay of Vehicle With the PrESENT OF ILLEGAL PARKING

\begin{tabular}{|l|l|l|l|}
\hline $\begin{array}{l}\text { Random seed } \\
(\mathbf{3 2})\end{array}$ & $\begin{array}{l}\text { Random seed } \\
\mathbf{( 4 2 )}\end{array}$ & $\begin{array}{l}\text { Random seed } \\
\mathbf{( 5 2 )}\end{array}$ & Average \\
\hline 44.28 & 42.03 & 46.15 & 44.15 \\
\hline
\end{tabular}

TABLE. V. Travel Time of Vehicle with the Present of ILlEGal PARKING

\begin{tabular}{|l|l|l|l|}
\hline $\begin{array}{l}\text { Random seed } \\
(\mathbf{3 2})\end{array}$ & $\begin{array}{l}\text { Random seed } \\
(\mathbf{4 2})\end{array}$ & $\begin{array}{l}\text { Random seed } \\
\mathbf{( 5 2 )}\end{array}$ & Average \\
\hline 134.28 & 149.41 & 135.18 & 139.62 \\
\hline
\end{tabular}

TABLE. VI. Shows Highway Capacity Manual Table of Los at INTERSECTION

\begin{tabular}{|l|l|l|}
\hline LOS & $\begin{array}{l}\text { Control Delay } \\
\text { Sec/veh (signalized) }\end{array}$ & $\begin{array}{l}\text { Delay } \\
\text { Sec/veh (unsignalised) }\end{array}$ \\
\hline A & $\leq 10$ & $\leq 10$ \\
\hline B & $10-20$ & $10-15$ \\
\hline C & $20-35$ & $15-25$ \\
\hline D & $35-55$ & $25-35$ \\
\hline
\end{tabular}

TABLE. VII. ARE SHOWING QUEUE LENGTH RESUlt FOR TRAFFIC FlOW SIMULATION

\begin{tabular}{|l|l|l|}
\hline Vehicle movement & & Queue length(m) \\
\hline \multirow{2}{*}{ From Parit Raja } & To Kluang & 24.13 \\
& To Parit Raja Laut & 24.13 \\
& To Batu Pahat & 47.86 \\
\hline \multirow{4}{*}{ From Batu Pahat } & To Kluang & 74.74 \\
& To Parit Raja Darat & 5.07 \\
& To Parit Raja Laut & 34.59 \\
\hline \multirow{2}{*}{ From Parit Raja } & To Kluang & 23.02 \\
Laut & To Parit Raja Darat & 14.67 \\
& To Batu Pahat & 14.67 \\
\hline \multirow{3}{*}{ From Kluang } & To Parit Raja Laut & 2.60 \\
& To Parit Raja Darat & 20.66 \\
& To Batu Pahat & 70.74 \\
\hline
\end{tabular}

Further analysis, level of service at the Parit Raja intersection could be evaluated by referring to the Highway Capacity Manual (HCM) [9] level of service on Table VI. Delay result from the simulation was used as a base to obtain LOS based on HCM. From the simulation results, delay of 44.15 for the studied intersection falls in the category of LOS D. This showed that the intersection was approaching unstable flow (tolerable delay, occasionally wait through more than one signal cycle before proceeding).

The impact of illegal parking elimination on Parit Raja intersection: In Parit Raja, illegal parking has become norm for local people which, then created problems with the surrounding traffic. Business activities on the road curbs by the road sides encourage illegal parking in Parit Raja particularly at the areas near to the intersection.
The study conducted had found that, on-road illegal parking had influenced the traffic flows particularly for left turn from Batu Pahat approach and Parit Raja Laut approach. This was due to either the reduction of the effective lane width or the lane has been taken by illegal vehicle parking that interrupted the vehicle movements. Furthermore, illegal parking activities near to the study location was also seen to disrupt the traffic through additional traffic delays due to stop delays caused by searching for parking or exiting parking. Fig. 10 shows that traffic to Ayer Hitam direction interrupted due to a cars stopped at the middle of the road. This situation happened because all cars needed to wait for a car at the illegal parking to enter the traffic.

Tables VIII and IX show the comparison of vehicle delay and travel time obtained from the simulation with and without the presence of illegal parking. The result had shown that, if illegal parking could be removed from the site, stop delay on each vehicle could be improved up to $21 \%$. This means traffic flows at the studied intersection could be increased. In addition, the result presented in Table IX, proved that, illegal parking was causing at least $20 \%$ of which was 47.17 seconds more than when illegal parking was eliminated in a driver travel time.

Table $\mathrm{X}$ shows the comparison of LOS of simulation result with presence of illegal parking, and without illegal parking. The result shows that, without the presence of illegal parking, LOS of intersection can be improved from $\mathrm{D}$ to $\mathrm{C}$.

TABLE. VIII. COMPARISON RESULTS OF STOP DELAY BETWEEN SIMULATION TRAFFIC FLOW WITH AND WITHOUT ILLEGAL PARKING

\begin{tabular}{|l|l|l|}
\hline Condition & $\begin{array}{l}\text { Without illegal } \\
\text { parking }\end{array}$ & $\begin{array}{l}\text { With illegal } \\
\text { parking }\end{array}$ \\
\hline Random seed (32) & 34.80 & 44.28 \\
\hline Random seed (42 & 32.74 & 42.03 \\
\hline Random seed (52) & 36.96 & 46.15 \\
\hline Average & 34.83 & 44.15 \\
\hline
\end{tabular}

TABLE. IX. COMPARISON RESULTS OF TRAVEL TIME BETWEEN SIMULATION TRAFFIC FLOW WITH AND WITHOUT ILLEGAL PARKING

\begin{tabular}{|l|l|l|}
\hline Condition & $\begin{array}{l}\text { Without illegal } \\
\text { parking }\end{array}$ & $\begin{array}{l}\text { With illegal } \\
\text { parking }\end{array}$ \\
\hline Random seed (32) & 92.11 & 134.28 \\
\hline Random seed (42 & 94.40 & 149.41 \\
\hline Random seed (52) & 90.83 & 135.18 \\
\hline Average & 92.45 & 139.62 \\
\hline
\end{tabular}

TABLE. X. COMPARISONS OF LOS WITH AND WITHOUT PRESENT OF ILLEGAL PARKING

\begin{tabular}{|l|l|l|}
\hline Condition & Delay result (second) & $\begin{array}{l}\text { Level of service } \\
\text { (second) }\end{array}$ \\
\hline Without illegal parking & 34.83 & $\mathrm{C}(>20-35)$ \\
\hline With illegal parking & 44.14 & $\mathrm{D}(>35-55)$ \\
\hline
\end{tabular}




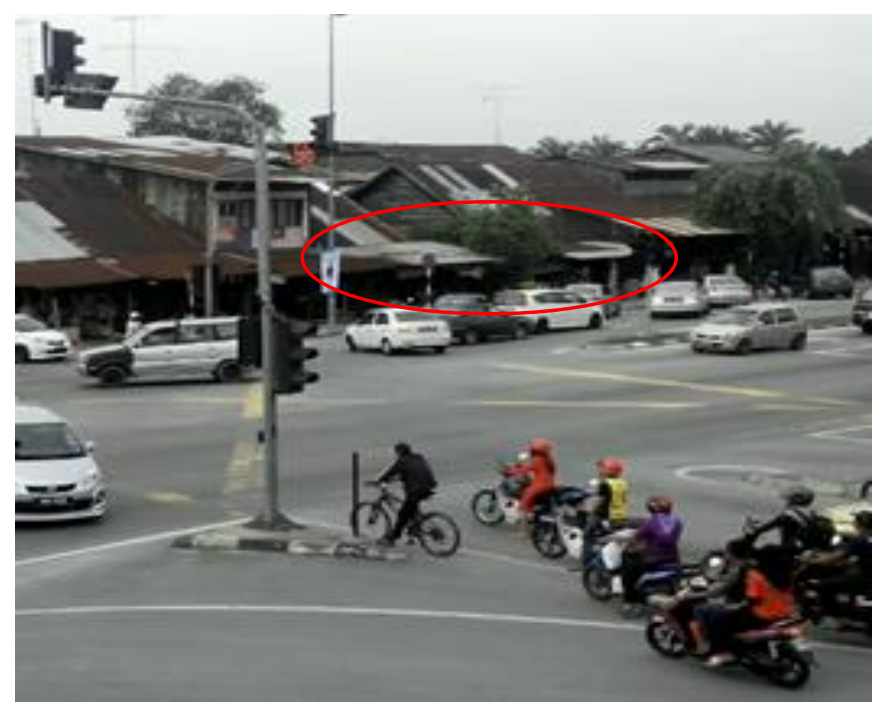

Fig. 10. Showing the Traffic Interruption due to Car Exit from Illegal Parking on Road.

\section{CONCLUSION}

The road network and base data were collected on-site and have been used in developing the simulation model using PTV VISSIM software. This was to ensure that the model could replicated the actual traffic condition. Other than that, PTV VISSIM needed to be calibrated and validate to make the data reliable [10].

Based on the simulation results and video recording of the study location in this study, illegal parking contributed to traffic flow disturbances. Removing illegal parking will help to upgrade the LOS, thus, contributes to smooth traffic flow. This was shown from the improvement of vehicle delay from 44.15 to 34.83 second. Besides that the travel time also has been found to improve by $20 \%$ which is 47.17 second less from when the illegal parking existed.

\section{ACKNOWLEDGMENT}

The authors gratefully acknowledge the contribution of the Ministry of Education and Universiti Tun Hussien Onn Malaysia. This paper was prepared as part of the research report under Research Grant of GPPS Vot H012.

\section{REFERENCES}

[1] J,Aderamo,A. Traffic Congestion at Road Intersections in Ilorin,Nigeria. Mediterranean Journal of Social Sciences, Volume 3(2),(2012),pp. 201213.

[2] Washington State Department of Transportation Manual.(2015). Chapter 1300-Intersection Control Type-Design Manual M22-01. In Intersection Control Type Design Manual (pp.1-20).

[3] Yan, X.,Radwan,E. and Abdel-aty,M. Characteristics of rear-end accident at signalized intersection using multiple logistic regression model. Accident Analysis and Prevention, Volume 37,(2005), pp.983995.

[4] Morillo Carbonell,C. and Campos Cacheda,J.M. Effect of Illegal On Street Parking On Travel Times In Urban Environment. CIT2016-XII Congreso de Ingeniera del Transporte Valencia,(2016),pp.24912503.Available at: http://dx.doi.org/10.4995/CIT2016.2016.3521.

[5] Boro,D.,M,A,Ahmed., and Goswami,A.Impact of On Street Parking on Traffic Flow Characteristics.Available at: https://www.academia.edu/ 25582493/Impact_of_OnStreet_Parking_on_Traffic_Flow_Characteristi cs? Auto.

[6] Tianzi,C.,Shaochen,J.I.N. and Hongxu,Y. Comparative study of VISSIM and SIDRA on signalized intersection. Procedia-Social and Behavioral Sciences,96(Cictp)(2013),pp.2004-2010.Available at: http://dx.doi.org/10.1016/j.sbspro.2013.08.226.

[7] PTV Group,(2004).VISSIM 4.10 User Manual, North America:PTV Planung Transport Verkehr AG.

[8] Nurul Nasuha,N.A. and Munzilah,M.D. Overview of Application Of Traffic Simulation Model.MATEC Web Conferences,(2018), Available at:https:doi.org/10.1051/matecconf/201815003006.

[9] Highway Capacity Manual,(2000).Signalized Intersection 4th ed., United Stated Transportation Research Board of the National Academies of Science.

[10] Rrecaj,A.A. and M,Bombol,K. Calibration and validation of the VISSIM parameter-state of the art. Technology, Education, Management, Informatics, Volume 4(3),(2015),pp.255-269. 